\title{
Pembangunan Green Belt Sebagai Antisipasi Pencemaran Udara Industri Pupuk Di Kalimantan Timur
}

\section{Green Belt Development as an Anticipation of Air Pollution in Fertilizer Industry, East Kalimantan}

\author{
JOKO PRAYITNO SUSANTO DAN WAGE KOMARAWIDJAJA \\ Pusat Teknologi Lingkungan, Badan Pengkajian dan Penerapan Teknologi \\ Gedung 820 Geostech, Kawasan Puspiptek Serpong, Tangerang Selatan \\ joko.susanto@bppt.go.id
}

\begin{abstract}
The fertilizer industry based on their environmental concerned in East Kalimantan is committed to protecting environmental sustainability and biodiversity which one of its efforts is to reduce the impact of air pollution by building Green Belt that serves as a buffer zone. The main element of the green belt is the vegetation that naturally acts as an atmospheric purifier by absorbing gaseous and particulate pollutants through its leaves. Green Belt Vegetation, with leafy and coarse leaf surfaces, with wide leaves, dense canopy with tight leaves expected to reduce air pollutant concentration from the fertilizer industry to surrounding residential areas. Thus the Green Belt will be built to help overcome the problem of air pollution impact in the settlement area around industrial area. sengon and teak.
\end{abstract}

Keywords: Green belt, fertilizer industry, air pollution, dust, particulates.

\section{ABSTRAK}

Industri pupuk ini bermaksud membangun proses industri pupuk yang ramah lingkungan untuk melindungi lingkungan dan keanekearagaman hayati dari pencemaran udara dengan membangun daerah penyangga dikenal sebagai sabuk hijau (Green Belt). Unsur utama sabuk hijau adalah vegetasi yang secara alamiah berfungsi sebagai pembersih atmosfir dengan menyerap polutan berupa gas dan partikel melalui daunnya. Vegetasi Green Belt, dengan permukaan daun berbulu dan kasar, dengan daun lebar, tajuk yang rapat dengan daun yang rapat diharapkan mampu mengurangi konsentrasi pencemar udara dari industri pupuk menuju areal permukiman disekitarnya. Dengan demikian Green Belt yang dibangun akan dapat membantu mengatasi masalah dampak pencemaran udara diareal permukiman sekitar kawasan industri.

Kata kunci: Sabuk hijau (green belt), industri pupuk, pencemaran udara, debu, partikulat.

\section{PENDAHULUAN}

\subsection{Latar Belakang}

Sabuk hijau (green belt), adalah ruang terbuka hijau (RTH) yang dibangun untuk membatasi tumbuh kembangnya suatu pemanfaatan lahan atau membatasi aktivitas satu dengan aktivitas lainnya, sehingga tidak saling mengganggu ${ }^{(1,2)}$. Sementara yang dimaksud dengan $\mathrm{RTH}$, adalah merupakan area yang memanjang dan atau mengelompok yang bersifat terbuka, digunakan utuk tumbuh kembang tanaman, baik yang tumbuh secara alamiah maupun yang sengaja ditanam ${ }^{(1,2,3)}$.

Kaltim Industrial Estate atau KIE adalah sebuah kawasan industri yang terletak di sebelah utara Kelurahan Lhoktuan, Kecamatan Bontang Utara, Kota Bontang, Kalimantan Timur. Industri ini menjadi satu kawasan dengan area industri pupuk milik PT Pupuk Kaltim dan berbatasan dengan kawasan permukiman penduduk
Kelurahan Lhoktuan (Gambar-1) ${ }^{(4,5)}$.

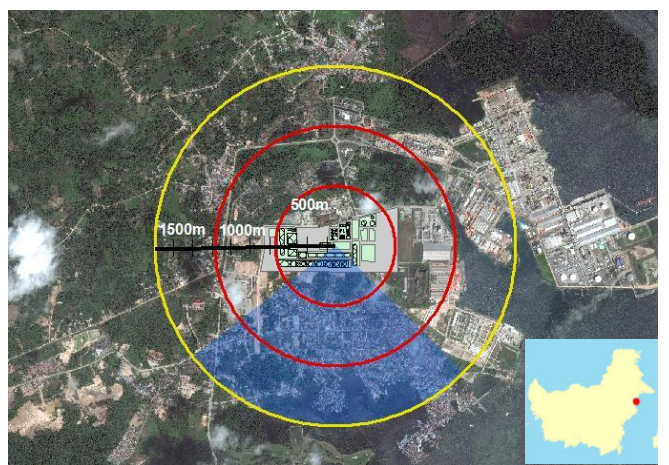

Gambar 1. Kawasan Kaltim Industrial Estate

Kawasan KIE ini merupakan pengembangan pabrik NPK Kluster, Asam Fosfat, Asam Sulfat, Aluminium Fluoride dan Gypsum, yang 
dikawatirkan berdampak negatif terhadap lingkungan, terutama akibat pencemaran udara yang ditimbulkan oleh beroperasinya industri tersebut ${ }^{(4,5)}$.

Oleh karena itu, adanya Green Belt pemisah antara areal industri dengan permukiman akan sangat berperan dalam mengantisipasi pencemaran udara yang berasal dari kawasan industri menuju kawasan permukiman(6). Adanya Green Belt tersebut antara lain dapat berperan sebagai :

a. Penahan dan Penyaring Partikulat .

Lahan Green Belt yang ditanami pepohonan dengan tajuk pohon yang tinggi dan rapat dapat membersihkan partikel padat yang tersuspensi yang melayang akan terjerap (menempel) pada permukaan daun, terutama daun yang berbulu dan permukaan yang kasar ${ }^{(1,8)}$.

b. Penyerap dan Penapis Bau

Lahan Green Belt disiapkan utuk mengurangi tingkat kebauan dapat dilakukan dengan menyiapkan tanaman dengan kemampuan menyerap bau secara langsung atau dengan mengembangkan penanaman tanaman yang menghasilkan bau harum sehingga dapat menetralisir bau busuk dan menggantinya dengan bau harum, seperti cempaka, dan tanjung. ${ }^{(1,9)}$.

c. Peredam Kebisingan

Lahan Green Belt disiapkan untuk mengantisipasi kebisingan dari sumber kawasan industri, memerlukan karakteristik tegakan pohon peredam kebisingan dengan tajuk tebal dan daun yang rindang. Daundaun tegakan pohon tersebut menurut hasil kajian mampu menyerap kebisingan higga $95 \%{ }^{(1,9)}$.

Luas lahan Green Belt yang berbatasan dengan kawasan permukiman Lhoktuan adalah kurang lebih 2,5 - 3.0 ha dengan lebar 50 meter dan panjang sekitar 600 meter, sebagaimana disajikan pada Gambar 2, sebagai rencana tapak Green Belt KIE $(4,5)$.

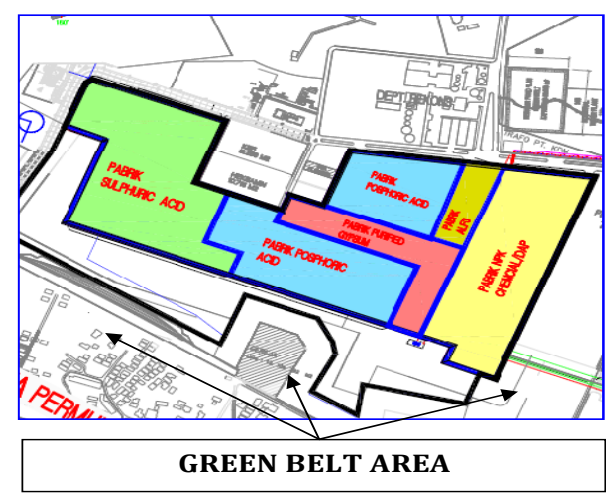

Gambar 2. Rencana Lokasi Green Belt di Kawasan Industri $\mathrm{KIE}^{(4,5)}$.

\subsection{Tujuan}

Telaah ini bertujuan memberikan gambaran upaya membangun sabuk hijau (Green-Belt) dalam rangka mengendalikan pencemaran udara.

\section{KONDISI LINGKUNGAN KAWASAN INDUSTRI}

\subsection{Kondisi Eksisting Kawasan KIE}

Kawasan rencana pembangunan industri pupuk KIE ini di sebelah Utara, Barat dan Timur berbatasan dengan kawasan pengembangan PKT, kecuali di sebelah Selatan yang berbatasan dengan kawasan permukiman Lhoktuan ${ }^{(4)}$.

Tapak rencana industri pupuk KIE tersebut dikenal sebagai Kawasan Industri Tursina Barat, semula merupakan daerah berbukit yang mempunyai ketinggian kurang lebih $50 \mathrm{~m}$ diatas permukaan air laut, dataran rendah dan berawa(4). Namun saat ini, kawasan tersebut, sebagian sudah mengalami perataan dan pengurugan, khususnya daerah dataran rendah dan berawa, sedangkan perbukitan di kawasan tersebut sebagian besar sudah mengalami pemotongan yang digunakan untuk pengurugan lahan lahan sekitarnya, sebagaimana disajikan pada Gambar $3^{(4)}$. Meskipun demikian secara keseluruhan, lahan tersebut masih memerlukan pengurugan, perataan dan pematangan ulang disesuaikan dengan kebutuhan pembangunan yang akan dilakukan oleh pihak PKT.

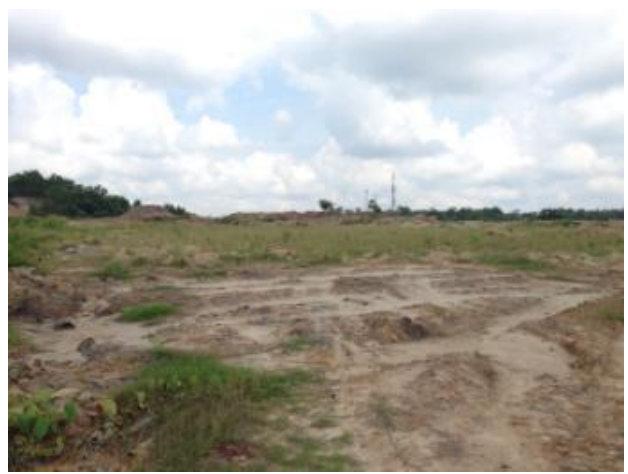

Gambar 3. Kondisi Umum Lahan Kawasan KIE

Di sebelah utara rencana pembangunan industri pupuk tersebut, terdapat kawasan industri green belt dengan karakterisitk terbangun dekat lahan green belt. Kondisi green belt yang tertutup tumbuhan yang rapat sangat kontras dengan kondisi lingkungan rencana industri pupuk KIE, sebagai disajikan pada Gambar $4^{(4,5)}$. 


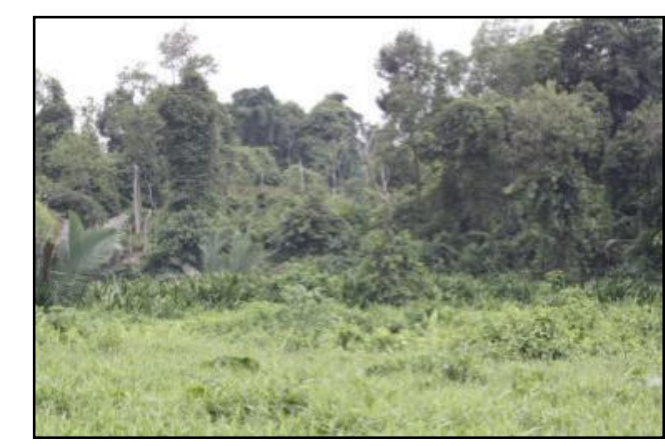

Gambar 4. Kondisi Umum Kawasan Green Belt Eksisting di Utara Kawasan KIE.

\subsection{Kualitas Udara Ambien}

Berdasarkan hasil pemantauan sebelumnya, disebutkan bahwa kualitas udara di kawasan rencana tapak industri pupuk KIEI, masih tergolong normal dan memenuhi baku mutu lingkungan PP No. 4 1999 tentang pengendalian pencemaran udara, sebagaimana disajikan pada Tabel 1, rata-rata hasil pemantauan kualitas udara ambien di dalam dan di luar pabrik selama 1 tahun ${ }^{(4)}$.

Demikian halnya untuk tingkat kebisingan, berdasarkah hasil pemantauan yang dilakukan selama 1 tahun pada tahun 2013, terlihat bahwa tingkat kebisingan pada wilayah studi (Guntung dan Lhoktuan) relatif sama yakni $54 \mathrm{~dB}(\mathrm{~A})$ dan belum melampaui tingkat bakumutu kebisingan kawasan permukiman. Hasil pemantauan kebisingan pada kedua lokasi tersebut berturut-turut adalah 54,16 $\pm 1,60 \mathrm{~dB}(\mathrm{~A})$ (Lhoktuan) dan $54,48 \pm 1,21 \mathrm{~dB}(\mathrm{~A})$ (Guntung) ${ }^{(4)}$.

Tabel 1. Kualitas udara ambien di sekitar Rencana industri pupuk KIE,Tahun $2013^{(4,5,6)}$.

\begin{tabular}{cllcc}
\hline Parameter & Unit & Lhoktuan & Guntung & $\mathrm{BML}^{*}$ ) \\
\hline $\mathrm{NO}_{2}$ & $\mu \mathrm{g} / \mathrm{m}^{3}$ & $6,92 \pm 1,91$ & $7,15 \pm 1,42$ & 400 \\
$\mathbf{N H}_{3}$ & $\mu \mathrm{g} / \mathrm{m}^{3}$ & $11,22 \pm 12,01$ & $9,91 \pm 9,78$ & $\left.1360^{\star *}\right)$ \\
Debu & $\mu \mathrm{g} / \mathrm{m}^{3}$ & $46,20 \pm 26,55$ & $69,52 \pm 33,45$ & 230 \\
\hline
\end{tabular}

Keterangan:

*) Baku Mutu, Kep. Men. LH. No. 50 Tahun 1996

**) Baku Mutu PP 41 Tahun 1999, tentang Pengendalian Pencemaran Udara (Baku Mutu Udara Ambien Nasional).

\subsection{Arah Angin di Rencana Lokasi Industri Pupuk KIE}

Berdasar analisis arah angin (windrose) di lokasi tapak pabrik-pabrik KIE, maka dapat disimpulkan bahwa arah angin yang mencapai kawasan permukiman adalah pada bulan September-Oktober mengarah ke sebagian permukiman di sebelah barat laut (Guntung) dan pada bulan Februari-Maret kearah Permukiman di Lhoktuan (Gambar-3) ${ }^{(5,6)}$.

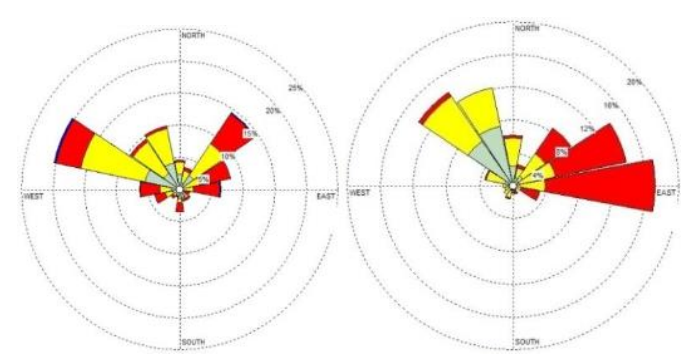

Februari 2015

Maret 2015

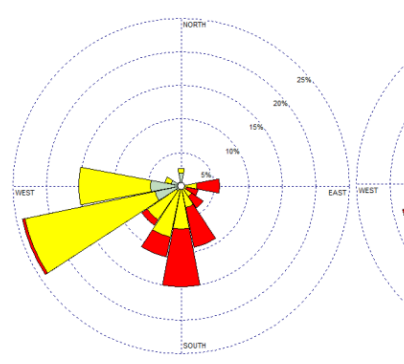

September 2015

Oktober 2015

Gambar 5. Arah dan Kecepatan Angin pada Bulan Feb.-Maret dan Sept.-Okt ${ }^{(4,5)}$.

\subsection{Pemodelan Emisi Industri Pupuk KIE.}

Model yang digunakan dalam pemetaan debu TSP dan emisi gas konvensional dari Kawasan Kaltim Industrial Estate adalah model yang advanced namun dimodelkan dalam skala sempit (reseptor dalam kisaran 10-20 km dari sumber). Dalam model ini dibutuhkan data emisi debu partikel dan emisi polutan gas konvensional (seperti: kecepatan keluar dari cerobong, temperatur kepulan, diameter cerobong), karakteristik kontur permukaan tanah (seperti: kekasaran permukaan, topografi lokal, bangunan setempat) dan kondisi atmosferik (seperti: kecepatan angin, stabilitas atmosfer, tinggi pencampuran). Model dispersi yang digunakan yaitu AERMOD View ver 8.9 (Lakes Environmental)(6).

Reseptor yang ditinjau secara detail adalah di LhokTuan karena lokasi ini sangat padat penduduk. Sumber emisi yang ditinjau adalah cerobong cerobong yang menghasilkan debu TSP serta emisi polutan gas konvensional lain (amoniak, sulfur dioksida dan fluor). Model ini digunakan untuk mensimulasikan konsentrasi cemaran di permukaan tanah pada konsentrasi maksimum yang terjadi(6).

Semula emisi fluor dari cerobong pabrik NPK chemical melebihi bakumutu untuk parameter fluor. Oleh karena itu dilakukan 
simulasi laju beban emisi Fluor dari Pabrik NPK Chemical dan Pabrik asam fosfat untuk mencapai baku mutu(6).

Dari hasil simulasi lanjutan yang dilakukan tersebut, konsentrasi Fluor dibawah bakumutu dicapai pada laju beban NPK Chemical $0.15 \mathrm{~g} / \mathrm{s}$ dan laju beban pabrik asam fosfat $0.1 \mathrm{~g} / \mathrm{s}$. Apabila laju beban pabrik asam fosfat tetap pada 0.22, maka untuk memenuhi baku mutu laju beban pabrik NPK Chemical dibuat $0.13 \mathrm{~g} / \mathrm{s}$ (6.5 - 13\% dari kondisi semula), sebagaimana disajikan pada Tabel 2. Untuk itu dibuat laju beban NPK Chemical turun 85\% sementara laju beban pabrik asam fosfat dibuat turun $45 \%$ (6).

Oleh karena itu, bilamana direncanakan untuk mempertahankan skala proses produksi di pabrik NPK Chemical, maka perlu ada modifikasi dalam teknologi pengendalian emisi gas fluor sehingga baku mutu udara ambiennya dapat terpenuhi. Teknologi yang digunakan untuk pengendalian emisi gas fluor antara lain adalah scrubber seperti cyclonic scrubber, venture scrubber dII $(4,5,6)$.

Uji model sebaran dilakukan dengan menggunakan data meteorologi tahun 2015, sebagaimana disajikan pada Gambar 4. Oleh karena itu, peluang perubahan konsentrasi emisi mungkin akan terjadi untuk tahun yang berbeda. Namun berdasar data yang digunakan dalam model tersebut, ternyata arah sebaran akan menimbulkan penumpukan polutan maksimum, tetapi tidak mengarah ke pemukiman Lhoktuan tapi kearah laut di Tenggara pabrik NPK Klaster(6).

Dengan demikian, dibangunnya industri pupuk terebut, secara matematis dan pemanfaatan teknologi dalam meminimasi emisi, mampu menekan kandungan emisi dari industri pupuk yang akan dibangun, sehingga kandungan emisinya tidak melebihi bakumutu.

\section{PEMBANGUNAN GREEN BELT}

\subsection{Jenis Tumbuhan Green Belt}

Jenis jenis vegetasi yang akan digunakan untuk membangun Green Belt dipilih dengn mempertimbangkan kondisi tapak, model tajuk dan tinggi pohon, kecepatan tumbuh dan pemeliharaan mudah, serta memiliki kemampuan penyerapan polutan yang optimal.

Penapisan terakhir untuk menentukan vegetasi yang akan diintroduksikan ke kawasan Green Belt adalah komposisi dan strata tanaman, sehingga dalam kawasan Green Belt akan dijumpai pohon tinggi, pohon sedang, perdu atau semak.
Tabel 5. Konsentrasi Maksimum 24 Jam Model Sebaran Simultan ${ }^{(6)}$.

\begin{tabular}{|c|c|c|c|c|c|}
\hline Pabrik & Parameter & $\begin{array}{c}\text { Laju Beban } \\
(\mathrm{g} / \mathrm{s})\end{array}$ & $\begin{array}{l}\text { Konsentrasi } \\
\text { Maksimum }\end{array}$ & $\begin{array}{c}\text { Bakumutu } \\
24 \mathrm{jam}\end{array}$ & Keterangan \\
\hline NPK Chemical & $\begin{array}{l}\text { Debu } \\
\text { Amonia }\end{array}$ & $\begin{array}{l}10.01 \\
10.01\end{array}$ & $\begin{array}{l}179 \mu \mathrm{\mu g} / \mathrm{Nm}^{3} \\
0.257 \mathrm{\mu g} \mathrm{Nm}^{3}\end{array}$ & $\begin{array}{l}230 \mu g \mathrm{Nm}^{3} \\
2 \mu \mathrm{gNm^{3 }}\end{array}$ & $\begin{array}{l}\text { Memenuhi BM } \\
\text { Memenuhi BM }\end{array}$ \\
\hline Asam Sulfat (SA) & $\mathrm{SO2}$ & 8.57 & $29.5 \mu \mathrm{g} / \mathrm{Nm}^{3}$ & $365 \mu \mathrm{g} \mathrm{Nm}^{3}$ & Memenuhi BM \\
\hline Asam Fossat (PA) & Debu & 1.10 & $2.57 \mu \mathrm{g} \mathrm{Nm}^{3}$ & $230 \mu \mathrm{g} \mathrm{Nm}^{3}$ & Memenuhi BM \\
\hline $\begin{array}{c}\text { NPK Chemical } \\
\text { Asam Fosíat (PA) }\end{array}$ & Fluor & $\frac{0.15(0.13)}{0.10(0.22)}$ & $2.74 \mu \mathrm{g} / \mathrm{Nm}^{3}$ & $3 \mu \mathrm{g} \mathrm{Nm}^{3}$ & Memenuhi BM \\
\hline
\end{tabular}

Secara umum, faktor-faktor yang perlu diperhatikan dalam memilih pohon untuk penghijauan Green Belt antara lain :

a. Perakaran yang dalam, kuat, tidak mudah tumbang \& tidak mudah menggugurkan ranting \& daun.

b. Mampu tumbuh di tempat terbuka di berbagai jenis tanah

c. Pertumbuhannya cepat \& tahan terhadap gangguan fisik

d. Tidak memerlukan perawatan yang intensif, berumur panjang, tahan terhadap kekurangan air

e. Pohon-pohon langka \& unggulan setempat

f. Pohon-pohon penghasil bunga/buah/biji yang bernilai ekonomis.

Beberapa literatur menyebutkan bahwa beberapa tanaman seperti Asam Jawa (Tamarindus indicus L), Angsana (Pterocarpus indicus Wild), Albasia (Falcataria molucana), Alba buto (Enterolobium cycleclocarfum), Acasia Mangium (Acasia mangium), dan Acasia Formis (Acasia auricoliformis) dapat disarankan sebagai tanaman zona Green Belt Kawasan Industri(10,11).

Dalam Tabel dibawah ini (Tabel 6 s.d. Tabel 10) disajikan beberapa jenis tanaman yang memiliki kemampuan menyerap Nitrogen (N), Karbon (C), Sulfur (S), dan Partikel Debu yang dapat dipertimbangkan sebagai potensi tanaman penghuni Green Belt.

Tabel 6. Alternatif Jenis Tumbuhan Berdasarkan Karaketristik Daun dan Pertumbuhan.

\begin{tabular}{|c|c|c|c|c|c|}
\hline \multirow[t]{2}{*}{ No. } & \multicolumn{2}{|c|}{ Spesies Tanaman } & \multicolumn{3}{|c|}{ Ciri Visual dan Pertumbuhan } \\
\hline & $\begin{array}{l}\text { Nama } \\
\text { Lokal }\end{array}$ & Nama Latin & $\begin{array}{c}\text { Tipe } \\
\text { Daun }\end{array}$ & $\begin{array}{l}\text { Warna } \\
\text { Daun }\end{array}$ & $\begin{array}{c}\text { Kecepatan } \\
\text { Tumbuh }\end{array}$ \\
\hline 1 & $\begin{array}{l}\text { Jati } \\
\text { Super }\end{array}$ & $\begin{array}{l}\text { Tectona } \\
\text { grandis }\end{array}$ & Besar & Hijau & Sedang \\
\hline 2 & Mahoni & $\begin{array}{l}\text { Swietenia } \\
\text { mahagoni }\end{array}$ & Sedang & Hijau & Lambat \\
\hline 3 & $\begin{array}{l}\text { Asam } \\
\text { Jawa }\end{array}$ & $\begin{array}{l}\text { Tamarindus } \\
\text { indica }\end{array}$ & Kecil & Hijau & Lambat \\
\hline 4 & $\begin{array}{l}\text { Cemara } \\
\text { Angin }\end{array}$ & $\begin{array}{l}\text { Casuarina } \\
\text { equisetifolia }\end{array}$ & Jarum & Hijau & Sedang \\
\hline 5 & $\begin{array}{l}\text { Jati } \\
\text { Putih }\end{array}$ & $\begin{array}{l}\text { Gimelina } \\
\text { arborea }\end{array}$ & Besar & Hijau & Cepat \\
\hline
\end{tabular}




\begin{tabular}{|c|c|c|c|c|c|}
\hline \multirow[t]{2}{*}{ No. } & \multicolumn{2}{|c|}{ Spesies Tanaman } & \multicolumn{3}{|c|}{ Ciri Visual dan Pertumbuhan } \\
\hline & $\begin{array}{l}\text { Nama } \\
\text { Lokal }\end{array}$ & Nama Latin & $\begin{array}{c}\text { Tipe } \\
\text { Daun }\end{array}$ & $\begin{array}{c}\text { Warna } \\
\text { Daun }\end{array}$ & $\begin{array}{c}\text { Kecepatan } \\
\text { Tumbuh }\end{array}$ \\
\hline 6 & Gayam & $\begin{array}{l}\text { Inocarpus } \\
\text { vagiferus }\end{array}$ & Sedang & Hijau & Sedang \\
\hline 7 & Tusam & Agatis alba & Sedang & Hijau & Rendah \\
\hline 8 & $\begin{array}{l}\text { Dadap } \\
\text { Merah }\end{array}$ & $\begin{array}{l}\text { Erythrina } \\
\text { variegata }\end{array}$ & Sedang & Belang & Sedang \\
\hline
\end{tabular}

Sumber: Patra, dkk., 2014. ${ }^{(12)}$

Tabel 7. Alternatif Vegetasi Berdasarkan Kemampuan Serapan Terhadap Nitrogen $\left({ }^{15} \mathrm{~N}\right)^{(12,13)}$

\begin{tabular}{|c|c|c|c|c|c|}
\hline \multirow{2}{*}{$\begin{array}{c}\text { No } \\
\text {. }\end{array}$} & \multicolumn{2}{|c|}{ Spesies Tanaman } & \multicolumn{3}{|c|}{ Serapan ${ }^{15} \mathrm{~N}(\mu \mathrm{g} / \mathrm{g} / 24 \mathrm{jam})$} \\
\hline & $\begin{array}{l}\text { Nama } \\
\text { Lokal }\end{array}$ & $\begin{array}{c}\text { Nama } \\
\text { Latin }\end{array}$ & $\begin{array}{c}\text { Kondisi } \\
\text { Gelap }\end{array}$ & $\begin{array}{l}\text { Kondisi } \\
\text { Terang }\end{array}$ & $\begin{array}{c}\text { Selisih } \\
\text { Serapan } \\
(\%)\end{array}$ \\
\hline 1 & $\begin{array}{l}\text { Jati } \\
\text { Super }\end{array}$ & $\begin{array}{l}\text { Tectona } \\
\text { grandis }\end{array}$ & 81.94 & 96.63 & 8.23 \\
\hline 2 & Mahoni & $\begin{array}{l}\text { Swietenia } \\
\text { mahagoni }\end{array}$ & 29.57 & 39.02 & 13.78 \\
\hline 3 & $\begin{array}{l}\text { Asam } \\
\text { Jawa }\end{array}$ & $\begin{array}{l}\text { Tamarindus } \\
\text { indica }\end{array}$ & 37.25 & 60.47 & 36.71 \\
\hline 4 & $\begin{array}{l}\text { Cemara } \\
\text { Angin }\end{array}$ & $\begin{array}{l}\text { Casuarina } \\
\text { equisetifolia }\end{array}$ & 28.62 & 33.84 & 8.36 \\
\hline 5 & $\begin{array}{l}\text { Jati } \\
\text { Putih }\end{array}$ & $\begin{array}{l}\text { Gimelina } \\
\text { arborea }\end{array}$ & 92.87 & 199.57 & 46.54 \\
\hline 6 & Gayam & $\begin{array}{l}\text { Inocarpus } \\
\text { vagiferus }\end{array}$ & 29.46 & 38.36 & 13.12 \\
\hline 7 & Tusam & Agatis alba & 22.17 & 23.22 & 2.31 \\
\hline 8 & $\begin{array}{l}\text { Dadap } \\
\text { Merah }\end{array}$ & $\begin{array}{l}\text { Erythrina } \\
\text { variegata }\end{array}$ & 54.52 & 73.29 & 14.69 \\
\hline
\end{tabular}

Tabel 8. Alternatif Vegetasi Berdasarkan Kemampuan Serapan Terhadap Karbondioksida $\left(\mathrm{CO}_{2}\right)^{(12,13)}$.

\begin{tabular}{|c|c|c|c|}
\hline No. & Nama Lokal & Nama Latin & $\begin{array}{c}\text { Daya Serap } \\
\text { Terhadap } \mathrm{CO}_{2} \\
\text { (kg/pohon/thn) }\end{array}$ \\
\hline 1 & Trembesi & Samanea saman & $28,488,39$ \\
\hline 2 & Kenanga & $\begin{array}{l}\text { Canangium } \\
\text { odoratum }\end{array}$ & 756.59 \\
\hline 3 & Beringin & Ficus benyamina. & 535.90 \\
\hline 4 & Mahoni & $\begin{array}{l}\text { Swietenia } \\
\text { mahagoni }\end{array}$ & 295.73 \\
\hline 5 & Bungur & $\begin{array}{l}\text { Lagerstroemia } \\
\text { speciosa }\end{array}$ & 160.14 \\
\hline 6 & Jati Super & Tectona grandis & 135.27 \\
\hline 7 & Nangka & $\begin{array}{l}\text { Arthrocarpus } \\
\text { heterophillus }\end{array}$ & 126.51 \\
\hline 8 & Johar & Casia grandis & 116.25 \\
\hline 9 & Puspa & Schima wallichii & 63.31 \\
\hline 10 & Acasia & $\begin{array}{l}\text { Acasia } \\
\text { auriculiformis }\end{array}$ & 48.68 \\
\hline 11 & Flamboyant & Delonix regia & 42.20 \\
\hline 12 & Tanjung & Mimusops elengi & 34.29 \\
\hline 13 & Sempur & Dilenia retusa & 24.24 \\
\hline 14 & Akasia & Acasia mangium & 15.19 \\
\hline 15 & Angsana & $\begin{array}{l}\text { Pterocarpus } \\
\text { indicus }\end{array}$ & 11.12 \\
\hline 16 & Asam Kranji & $\begin{array}{l}\text { Pithecelobium } \\
\text { dulce }\end{array}$ & 8.48 \\
\hline 17 & Dadap Merah & $\begin{array}{l}\text { Erythrina } \\
\text { variegata }\end{array}$ & 4.55 \\
\hline
\end{tabular}

\begin{tabular}{lllc}
\hline No. & Nama Lokal & Nama Latin & $\begin{array}{c}\text { Daya Serap } \\
\text { Terhadap } \mathrm{CO}_{2} \\
\text { (kg/pohon/thn) }\end{array}$ \\
\hline $\mathbf{1 8}$ & Asam Jawa & $\begin{array}{l}\text { Tamarindus } \\
\text { indica }\end{array}$ & 1.49 \\
\hline
\end{tabular}

Sumber: Tanjung, 2003.

Tabel 9. Alternatif Tumbuhan Green Belt Berdasarkan Kemampuan Serapan Terhadap Sulfur dioksida $\left(\mathrm{SO}_{2}\right)^{(12,13)}$

\begin{tabular}{|c|c|c|c|}
\hline No. & Nama Lokal & Nama Latin & $\begin{array}{c}\text { Daya Serap } \\
\text { Terhadap } \\
\mathrm{SO}_{2}(\% \mathrm{~S})\end{array}$ \\
\hline 1 & Beringin & Ficus $s p$. & 0.3444 \\
\hline 2 & Eucalyptus & $\begin{array}{l}\text { Eucalyptus } \\
\text { urograndis }\end{array}$ & 0.3003 \\
\hline 3 & AgathisDamar & $\begin{array}{l}\text { Agathis } \\
\text { dammara }\end{array}$ & 0.2391 \\
\hline 4 & Mangium/Acasia & $\begin{array}{l}\text { Acasia } \\
\text { mangium }\end{array}$ & 0.2094 \\
\hline 5 & Jambu & Psidium guava & 0.1796 \\
\hline 6 & Kemiri & $\begin{array}{l}\text { Alleurites } \\
\text { moluccana }\end{array}$ & 0.1552 \\
\hline 7 & Nangka & $\begin{array}{l}\text { Artocarpus } \\
\text { integra }\end{array}$ & 0.0987 \\
\hline
\end{tabular}

Tabel 10. Alternatif Tumbuhan Berdasarkan Kemampuan Serapan Terhadap Debu Partikulat ${ }^{(12,13)}$

\begin{tabular}{lllc}
\hline No. & Nama Lokal & Nama Latin & $\begin{array}{c}\text { Daya Serap } \\
\text { Terhadap } \\
\text { debu }(\mathbf{g} / \mathbf{m} 3)\end{array}$ \\
\hline $\mathbf{1}$ & Asam Keranji & Dialium indum & 76.3 \\
$\mathbf{2}$ & Sonokeling, & Dalbergia latifolia & 41.6 \\
$\mathbf{4}$ & Mindi & Melia azedarach & 37.5 \\
$\mathbf{3}$ & Sengon & Albizia chinensis & 34.6 \\
$\mathbf{5}$ & Jambu Air & Syzyangium & 34.1 \\
\hline \multicolumn{2}{c}{ Sumber: } & aqueum &
\end{tabular}

Sumber: Tanjung, 2003

\subsection{Jumlah dan Kompisisi Jenis Tumbuhan Green Belt.}

Dari hasil analisis deskriptif Tabel Tabel diatas, dapat diketahui bahwa terdapat jenis tumbuhan dengan tajuk tinggi, tajuk sedang dan perdu atau semak belukar. Dengan mengkombinasikan tumbuhan dapat disusun suatu komposisi Green Belt dengan strata tegakan yang mewakili tegakan tinggi, tegakan sedang dan semak belukar.

Oleh karena itu, berdasarkan faktor faktor penentu pemilihan tanaman penghijauan green Belt diatas, maka tumbuhan yang akan diintroduksikan ke zona Green Belt adalah sebagai berikut, sebagaimana disajikan pada Tabel 11.

Ada beberapa hal yang perlu menjadi pedoman menentukan alternatif tanaman Green Belt, mengingat bahwa tanaman tersebut harus memenuhi beberapa kriteria 
yang dibutuhkan dibangunya Green Belt ini. Kriteria tersebut adalah sebagai berikut, bahwa Green Belt selain berfungsi sebagai zona hijau pembatas antara kawasan industri dengan kawasan Permukiman juga berfungsi :

1) Tanaman yang diintroduksi memiliki kapasitas menyerap debu yang terpapar ke zona Green Belt.

2) Tanaman yang diintroduksi memiliki kapasitas menyerap gas pencemar yang dihasilkan pabrik pupuk.

3) Tanaman yang diintroduksi memiliki kapasitas mengurangi bau dari emisi pabrik yang timbul.

Tabel 11. Alternatif Komposisi Tumbuhan Green Belt

\begin{tabular}{|c|c|c|c|}
\hline No & Nama Lokal & Nama Latin & Serapan \\
\hline 1 & Angsana & $\begin{array}{l}\text { Pterocarpus } \\
\text { indicus }\end{array}$ & $\mathrm{CO}_{2}$ \\
\hline 2 & Flamboyant & Delonix regia & $\mathrm{CO}_{2}$ \\
\hline 3 & Puspa & Schima wallichii & $\mathrm{CO}_{2}$ \\
\hline 4 & Kenanga & $\begin{array}{l}\text { Canangium } \\
\text { odoratum }\end{array}$ & $\mathrm{Bau}$ \\
\hline 5 & Tanjung & Mimusops elengi & $\mathrm{Bau}$ \\
\hline 6 & Mahoni & $\begin{array}{l}\text { Swietenia } \\
\text { mahagoni }\end{array}$ & $\mathrm{N}$ \\
\hline 7 & $\begin{array}{l}\text { Dadap } \\
\text { Merah }\end{array}$ & $\begin{array}{l}\text { Erythrina } \\
\text { variegata }\end{array}$ & $\mathrm{N}$ \\
\hline 8 & Asam Jawa & $\begin{array}{l}\text { Tamarindus } \\
\text { indica }\end{array}$ & $\mathrm{N}$ \\
\hline 9 & Nangka & $\begin{array}{l}\text { Arthrocarpus } \\
\text { heterophillus }\end{array}$ & S \\
\hline 10 & Beringin & Ficus benyamina. & $\mathbf{S}$ \\
\hline 11 & Acasia & $\begin{array}{l}\text { Acasia } \\
\text { auriculiformis }\end{array}$ & S \\
\hline 12 & Kemiri & $\begin{array}{l}\text { Alleurites } \\
\text { moluccana }\end{array}$ & $\mathbf{S}$ \\
\hline 13 & Jambu & Psidium guava & S, debu \\
\hline 14 & Sengon & Albizia chinensis & debu \\
\hline 15 & Asam Kranji & $\begin{array}{l}\text { Pithecelobium } \\
\text { dulce }\end{array}$ & CO2, Debu \\
\hline
\end{tabular}

Dengan memperhatikan fungsi Green Belt diatas, maka dipilih beberapa jenis tumbuhan yang memiliki kapasitas dalam mendukung fungsi $1 \mathrm{~s} / \mathrm{d} 3$, sebagaimana disajikan pada Tabel 9.

\subsection{Konsep Strata Tumbuhan dan Landscape Green Belt}

Untuk menempatkan dan menumbuh kembangkan jenis-jenis tanaman pada Tabel 7 , dapat dipilih dari 2 (dua) alternatif konsep pembangunan Green Belt tersebut, sebagai berikut :

1) Konsep (a), setiap jenis tanaman menempati lahan Green Belt sesuai dengan strata tanaman (tajuk Tinggi dan Tajuk sedang), lihat Gambar-5(a).

Konsep (b), setiap jenis tanaman menempati lahan sesuai dengan strata tanaman (tajuk Tinggi dan Tajuk sedang), tetapi ada tanaman tajuk sedang yang intersep dibawah tanaman tajuk tinggi, lihat Gambar-5(b).

Tabel 12. Komposisi Tumbuhan Green Belt PT KIE

\begin{tabular}{|c|c|c|c|c|}
\hline No & $\begin{array}{l}\text { Nama } \\
\text { Lokal }\end{array}$ & Nama IImiah & $\begin{array}{c}\text { Strata } \\
\text { Veg. }\end{array}$ & Ket \\
\hline 1 & $\begin{array}{l}\text { Asam } \\
\text { Kranji }\end{array}$ & P. dulce & Tajuk tinggi & $\begin{array}{l}\mathrm{CO} 2 \\
\text { Debu }\end{array}$ \\
\hline 2 & Mahoni & S. mahagoni & Tajuk tinggi & $\mathrm{N}$ \\
\hline 3 & Kenanga & C. odoratum & Tajuk tinggi & Bau \\
\hline 4 & Tanjung & M. elengi & Tajuk tinggi & $\mathrm{Bau}$ \\
\hline 5 & Kemiri & A. moluccana & Tajuk tinggi & $\begin{array}{l}\text { S, } \\
\text { debu }\end{array}$ \\
\hline 6 & Sengon & A. chinensis & $\begin{array}{c}\text { Tajuk } \\
\text { sedang }\end{array}$ & debu \\
\hline 7 & $\begin{array}{l}\text { Dadap } \\
\text { merah }\end{array}$ & E. variegata & $\begin{array}{l}\text { Tajuk } \\
\text { sedang }\end{array}$ & $\mathrm{N}$ \\
\hline 8 & Acasia & $\begin{array}{l}\text { A. } \\
\text { auriculiformis }\end{array}$ & $\begin{array}{l}\text { Tajuk } \\
\text { sedang }\end{array}$ & $S$ \\
\hline 9 & Flamboyan & D. regia & $\begin{array}{l}\text { Tajuk } \\
\text { sedang }\end{array}$ & $\mathrm{CO} 2$ \\
\hline
\end{tabular}

Sumber: dirangkum dari beberapa sumber

Dengan pertimbangan lebar Green Belt hanya mencapai 50 meter, untuk mendapatkan landscape yang optimal, Konsep (b) merupakan konsep yang mendapat pertimbangan untuk ditidak lanjuti

Pada Konsep (b), sisi kearah permukiman ditempatkan tanaman bertajuk tinggi sekaligus memilki fungsi menangkap partikulat dan polutan gas dengan tajuknya yang menjulang, selanjutnya dibagian bawah tajuk tinggi tumbuh tanaman tajuk rendah dengan fungsi yang sama akan menyerap partikulat dan polutan gas.

Demikian juga untuk sisi Green Belt kearah pabrik ditumbuhi tanaman tajuk sedang dan semak, yang juga berfungsi untuk menyerap partikulat dan menyerap polutan gas. Sedangkan kebauan yang berasal dari operasi pabrik diharapkan dapat tereliminasi oleh tebalnya lapisan Green Belt sekaligus dikurangi oleh tanaman yag menghasilkan wewangian seperti Kenangan dan Tanjung.

\subsection{Kerapatan Tumbuhan}

Pada dasarnya jumlah tanaman yang diperlukan pada luasan tertentu, dipengaruhi 
oleh rencana jarak tanam yang akan dijadikan patokan. Diketahui bahw jarak tanam setiap jenis pohon sangat beragam, tergantung dari tujuan yang ditargetkan. Untuk tanaman bertajuk tinggi ada yang menggunakan jarak tanam 10x10 meter, 10x8 meter. Dan utuk tanaman bertajuk rendah ada yang berjarak tanam $4 \times 4$ meter, $4 \times 3$ meter, dsb.

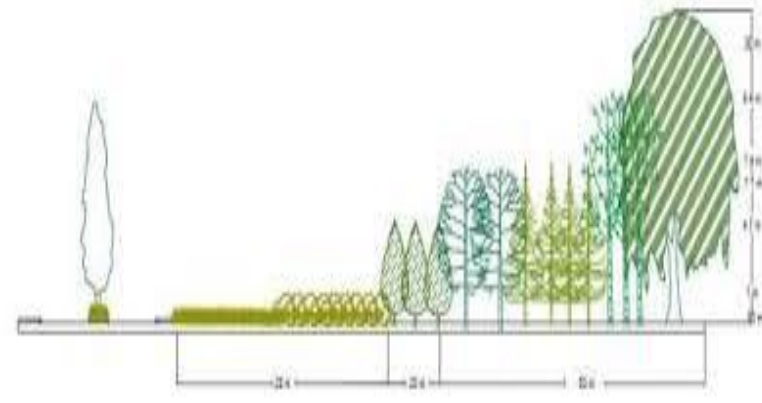

(a)

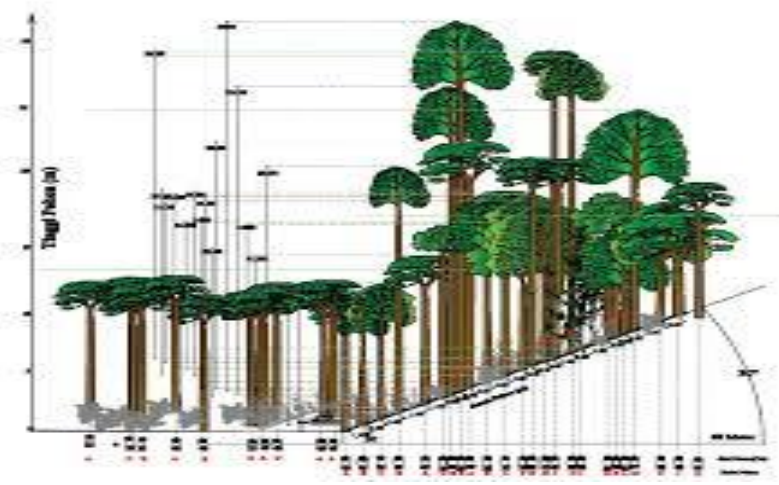

(b)

Gambar 6. Konsep a dan c; Introduksi Komposisi dan Strata Tanaman Green Belt.

Berdasarkan beberapa pertimbangan, dalam melakukan introduksi tanaman di Green Belt, jarak tanam ditetapkan $10 \times 10$ meter untuk tanaman bertajuk tinggi dan $5 \times 5$ meter untuk tanaman bertajuk sedang. Tanaman bertajuk tinggi akan menepati $60 \%$ lahan Green Belt yang mendekati kawasan Permukiman. Tanaman bertajuk sedang akan menempati 100\% lahan Green Belt, dimana sebagian tanaman bertajuk sedang ini, ada yang ditanam diantara pohon bertajuk tinggi.

Oleh karena itu, untuk Green Belt PT KIE dengan luas lahan lebih kurang $30000 \mathrm{~m} 2$ yang berukuran (panjang $x$ lebar) 600x 50 meter, maka jumlah dibutuhkan tanaman sebanyak 1200 pohon, dengann rincian 180 pohon bertajuk tinggi dan 1020 pohon bertajuk sedang. Untuk tanaman tajuk sedang, 540 pohon ditanam dalam satu lokasi dengan tajuk tinggi dan 480 pohon ditanam disisa lahan $(40 \%)$. Secara rinci kebutuhan jenis tanaman untuk Gren Belt ini disajikan pada Tabel 13. Dengan mengimplementasikan Konsep (b), perkembangan yang akan terjadi diharapkan seperti yang disajikan pada Gambar- 6

Tabel 13. Kebutuhan Jumlah Pohon per jenis Tumbuhan Green Belt PT KIE

\begin{tabular}{|c|c|c|c|c|}
\hline No. & $\begin{array}{l}\text { Nama } \\
\text { Lokal }\end{array}$ & Nama Latin & $\begin{array}{l}\text { Pera } \\
\text { n }\end{array}$ & $\begin{array}{l}\text { Jumlah } \\
\text { Pohon }\end{array}$ \\
\hline I. & Tajuk Tinggi & & & \\
\hline 1 & $\begin{array}{l}\text { Asam } \\
\text { Kranji }\end{array}$ & P. dulce & $\begin{array}{l}\text { CO2, } \\
\text { Debu }\end{array}$ & 60 \\
\hline 2 & Mahoni & S. mahagoni & $N$ & 20 \\
\hline 3 & Kenanga & C. odoratum & Bau & 20 \\
\hline 4 & Tanjung & M. elengi & Bau & 20 \\
\hline \multirow[t]{2}{*}{5} & Kemiri & A. moluccana & $\begin{array}{c}\text { S, } \\
\text { debu }\end{array}$ & 60 \\
\hline & & Sub Total & & 180 \\
\hline II. & Tajuk Sedang & & & \\
\hline 6 & Acasia & $\begin{array}{l}\text { A. } \\
\text { auriculiformis }\end{array}$ & $\mathbf{s}$ & 360 \\
\hline 7 & Sengon & A. chinensis & debu & 480 \\
\hline 8 & $\begin{array}{l}\text { Dadap } \\
\text { Merah }\end{array}$ & E. variegata & $N$ & 120 \\
\hline \multirow[t]{3}{*}{9} & Flamboyant & D. regia & $\mathrm{CO} 2$ & 60 \\
\hline & & Sub Total & & 1020 \\
\hline & $T O T A L$ & & & 1200 \\
\hline
\end{tabular}

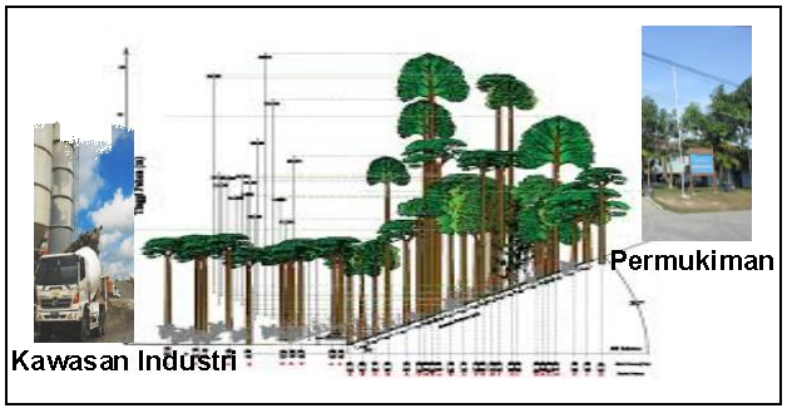

Gambar 7. Stratifikasi Vegetasi Green Belt PT KIE.

\subsection{Manfaat Green Belt Industri Pupuk KIE}

Pembangunan sabuk hijau atau Green Belt dimaksudkan sebagai pilihan dalam rangka pembangunan yang tidak merusak lingkungan ${ }^{(1)}$

Selain melakukan penerapan teknologi untuk menekan praoduksi limbah yang dihasilkan dalam industri proses, beberapa literatur menunjukkan bahwa penanaman tumbuhan dalam konsep greenbelt mampu menurunkan kualitas udara ambien pada suatu wilayah tertentu(14,15,16,17,18,19,20,21,22,23).

Dengan pilihan pilihan tanaman yang tepat dan luasan areal tertentu akan mampu menurunkan polusi suatu industri $(1,12,13)$. Beberapa kajian dengan lebar green belt mencapai 500 meter, Green belt mampu 
menurunkan polusi udara suatu kawasan(24,25), sebaliknya dengan lebar green belt yang terbatas, seperti ditepian jalan raya, upaya tersebut tidak maksimal menurunkan kandungan pencemaran udara ambien ${ }^{(26,27,28)}$.

Dengan alasan tersebut, ada suatu kehawatiran, rencana pembangunan Green Belt dengan lebar 50 dan panjang 600 meter di rencana kawasan industri $\mathrm{KIE}^{(5)}$, tidak menghasilkan penurunan polusi udara yang signifikan(26,27,28). Hanya saja, untuk rencana kawasan industri pupuk KIE, selain kualitas udara ambien eksisiting yang masih baik ${ }^{(4,5)}$, hasil simulasi model konsentrasi gas buang dari cerobong rencana industri pupuk KIE telah memenuhi ketentuan baku mutu(6).

\section{KESIMPULAN}

Dengan membangunan kawasan Green Belt, secara estetika kawasan industri menjadi nyaman, dan sekaligus mengurangi pencemaran udara daerah sekitarnya, terutama kawasan permukiman yang berdampingan dengan kawasan industri(14,15,16,17,18). Dalam mempersiapkan tanaman untuk ditanam di lahan Green Belt, telah dipilih alternatif jenis tanaman yang berfungsi menyerap gas pencemar, menyerap partikulat, dan aroma bau dari bahan kimia yang terlepas dari aktifitas industri(1,12,13). Komposisi tanaman yang diusulkan untuk menyusun tanaman green belt telah dipilih sesuai kebutuhan ${ }^{(26,27,28)}$.

\section{PERSANTUNAN}

Ucapan terima kasih disampaikan kepada Bapak Prof. Dr. Ir. Yudhi Soertrisno Garno, MSc, yang telah memberikan kritik dan saran dalam menyusun naskah ini. Tidak lupa kepada teman sejawat yang tidak dapat disebutkan satu persatu, yang telah membantu dan mendukung proses penelitian, dan dokumentasi hasil penelitian ini

\section{DAFTAR PUSTAKA}

1. Anonim. (2008). Lampiran Peraturan Menteri PU nomor 05/PRT/M/2008 tentang Pedoman Penyediaan dan Pemanfaatan Ruang Terbuka Hijau di Kawasan Perkotaan. Direktorat Jenderal Penataan Ruang, Departemen Pekerjaan Umum

2. Marmi (2016). Ruang Terbuka Huijau (RTH) Kota Surabaya sebagai Wahana Peningkatan Kemampuan Dasar Sistimatik Tumbuhan, Inovasi Vol.18, No.1, Hal: 72-79.

3. Saraswati, A. A. (2008) Keberadaan Ruang Terbuka Hijau dalam Pembangunan Kawasan
Industri, Jurnal Teknologi Lingkungan (JTL), Edisi Khusus, Juli 2008, Hal:1-8. ISSN 1441318X.

4. Pupuk Kaltim. (2014), Laporan Akhir: Studi Pemilihan Lokasi Pabrik NPK Cluster Proyek NPK Cluster, PT. Pupuk Kalimantan Timur, Pusat Pelayanan Teknologi/Bppt Enjiniring, Badan Pengkajian dan Penerapan Teknologi

5. Pupuk Kaltim. (2016(a)), Laporan Akhir: Studi Penanganan Aspek Lingkungan Pembangunan Pabrik NPK Cluster, Kaltim Industrial Estate, Kantor Pusat Dan Pusat

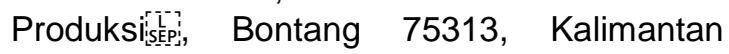
Timur, Indonesia.

6. Pupuk Kaltim. (2016(b)), Laporan Akhir: Kajian Prediksi Sebaran Emisi Hipotetik di Area NPK Klaster, Kaltim Industrial Estate, Kantor Pusat Dan Pusat Produksilisepi, Bontang 75313, Kalimantan Timur, Indonesia.

7. Basri, I. S. (2009). Jalur Hijau (Green Belt) sebagai Kontrol Polusi Udara Hubungannya dengan Kualitas Hidup di Perkotaan, Jurnal Smartek. Vol. 7, No. 2, Hal :113 - 120.

8. Samsoedin, I. dan E. Subiandono. (2007). Pembangunan dan Pengelolaan Hutan Kota, Prosiding Ekspose Hasil-hasil Penelitian, Pusat Litbang Hutan dan Konservasi Alam Bogor

9. Grey, G.W. dan F.I. Deneke. (1978). Urban Forestry. John Wiley and Sons.

10.Fakhrian, R., H. Hindersah, dan $H$. Burhanudin. (2015). Arahan Pengembangan Sabuk Hijau (Green Belt) di Kawasan Industri Kariangau (KIK) Kota Balikpapan. Prosiding Penelitian Spesia 2015 "Perencanaan Wilayah dan Kota", Tahun Akademik 20142015: 15-20.

11.Wahyudi, (2009) Ketersediaan Alokasi Ruang Terbuka Hijau Kota Pada Ordo Kota I Kabupaten Kudus, Tesis, Program Magister Ilmu Lingkungan Program Pasca Sarjana, Universitas Diponegoro.

12.Patra, A.D., N. Nasrullah, dan E.L. Sisworo. (2014). Kemampuan Berbagai Jenis Tanaman Menyerap Gas Pencemar Udara $\left(\mathrm{NO}_{2}\right)$, Risalah Seminar IImiah Penelitian dan Pengembangan Aplikasi Isotop dan Radiasi. Batan-Jakarta.

13.Kusminingrum, N. (2008). Potensi Tanaman dalam Menyerap $\mathrm{CO}_{2}$ dan $\mathrm{CO}$ untuk Mengurangi Dampak Pemanasan Global, Jurnal Pemukiman Volume 3, Nomor 2: 96105.

14. Maryuhembri. (2016). Kapabilitas Pemerintah Daerah Kabupaten Kuantan Singingi dalam 
Pengelolaan Ruang Terbuka Hijau (RTH) Tahun 2011-2015, JOM Fisip Volume 4, Nomor 1: 1-15

15. Hastuti, I. (2012). Penyediaan Ruang Terbuka Hijau Berdasarkan Nilai Emisi $\mathrm{CO}_{2}$ di Kawasan Industri Surabaya. Tugas Akhir, Institut Teknologi Sepuluh Nopember, Surabaya.

16.Lestari, I., B. Yanuwiadi, dan Soemarno, (2013). Analisis Kesesuaian Vegetasi Lokal untuk Ruang Terbuka Hijau Jalan Jalan di Pusat Kota Kupang, J-PAL, Volume 4, Nomor $1: 1-10$, ISSN 2087-3522 dan E-ISSN 23381671.

17.Mediastika, C. E. (2002). Memanfaatkan Tanaman untuk Mengurangi Polusi Particulate Matter ke Dalam Bangunan, Dimensi Teknik Arsitektur Volume 39, Nomor 2 : 159-166

18. Hastuti, E., dan T. Utami. (2008). Potensi Ruang Terbuka Hijau dalam Penyerapan $\mathrm{CO}_{2}$ di Permukiman, Jurnal Pemukiman Volume 3 , Nomor 2: 106-114.

19.Mulyadin, R. M., dan R. E. P. Gusti. (2015). Analisis Kebutuhan Luasan Areal Hijau Berdasarkan Daya Serap $\mathrm{CO}_{2}$ di Kota Malang, jawa Timur, Jurnal Penelitian Sosial dan Ekonomi Kehutanan Volume 12, Nomor 1: 59-66.

20.Tang, B. S., S. W. Wong, and A. K. W. Lee. (2007). Green Belt in a Compact City: A Zone for Conservation or Transition Landscape and Urban Planning, Vol. 79: pp 358-373.

21.Nowak, D. J., D. E. Crane, and J. C. Stevens. (2006). Air Polution removal by Urban Trees in the United States, Urban Forestry \& Urban Greening, Vol. 4 : pp 115-123.
22.Yang, J., J. McBride, J. Zhou, and Z. Sun. (2005). TheUrban Forest in Beijing and Its Role in Air Pollution Reduction, Urban Forestry \& Urban Greening, Vol. 3 : pp 65-78.

23.Subramani, S., and Devaanandan. (2015). Application of Air Pollution Tolerance Index in Assesing the Air Quality, International Journal of Pharmacy and Pharmaceutical Science, Vol. 7, Issue 7: pp 216-221, ISSN 0975-1491.

24.Gupta, R. B., P. R. Chaudhari, and S. R. Wate. (2008). Overview on Attenuation of Industrial Air Pollution by Greenbelt, J. of Industrial Pollution Control Vol 25, No. 1: pp $1-8$

25.Rao, P. S., A. G. Gavane, S. S. Ankam, M. F. Ansari, V. i. Pandirt, and P. Nema. (2004). Performance Evaluation of a Green Belt in a Petroleum Refinery: A Case study, Ecological Enggineering No. 21: pp 77-84.

26. Martuti, N. K. T. (2013). Peranan Tanaman terhadap Pencemaran Udara di Jalan Protokol Kota Semarang, Biosaitifikas, Vol. 5, No. 1:36-42. Ttg:tanaman tdk berpengaruh, mungkin jenis tdk sesuai dgn polutannya.

27. Yli-Pelkonen, V., H. Setala, V. Viippola. (2017). Urban Forest Near Roads Do not Reduce Gaseous Air Pollutant Concentration but Have an Impact on particles levels, Lanscape and Urban Planning Vol. 158 :pp 39-47. www. Elsivier.com/locate/landurbplan.

28. Yli-Pelkonen, V., H. Setala, V. Viippola. (2017). Greenbelts Do not Reduce NO2 Concentrations in Near-road Environment, Urban Climate Vol 21: pp 306-317, Elsivier.com/locate/uclim. 
